\title{
Total Suspended Particulate Matter (TSP) and Its Associated Heavy Metals in Atmosphere on the Western Coast of Saudi Arabia
}

\author{
Jalal M. Basahi ${ }^{1,2}$, Iqbal M. Ismail ${ }^{1}$, Ibrahim A. Hassan ${ }^{1,2 *}$, \\ Talal Almeelbi ${ }^{1,2}$, Nesreen S. Haiba ${ }^{4}$, Essam Hammam ${ }^{5}$ \\ ${ }^{1}$ Air Pollution Laboratory (APL), Centre of Excellence in Environmental Studies (CEES), \\ King Abdulaziz University, Jeddah 21589., Jeddah KSA \\ ${ }^{2}$ Faculty of Meteorology, Environment and Arid Land Agriculture, \\ King Abdulaziz University, Jeddah, Saudi Arabia \\ ${ }^{3}$ Faculty of Science, Alexandria University, 21526 El Shatby, Alexandria, Egypt \\ ${ }^{4}$ Department of Chemistry and Physics, Faculty of Education, Alexandria University, Egypt \\ ${ }^{5}$ Department of Chemistry and Biochemistry, University of North Carolina Wilmington, \\ 601 S. College Road, Wilmington, NC 28403, USA
}

Received: 30 January 2017

Accepted: 22 February 2017

\begin{abstract}
Total suspended particulates (TSP) in ambient air of three sites representing a gradient transect of urbanization along the western coast of Saudi Arabia were collected and their heavy metal contents were analyzed. The sampling was conducted at three sites simultaneously between 16 June to 7 July 2013, 17 September to 1 October 2013 (summer), and 23 December 2013 to 30 January 2014 (winter). The concentration of TSP was very high in ambient air of the two northern sites, ranging between 73 and $883 \mu \mathrm{g} \mathrm{m}^{-3}$ in the far northern site (Rayes, industrial) which is located south to Yanbu industrial city, and it was between 64 and $251 \mu \mathrm{g} \mathrm{m}^{-3}$ in the other site (Rabegh, urban). The southern site (Abhur, residential) showed relatively lower levels of TSP (ranging between 54 and $339 \mu \mathrm{g} \mathrm{m}^{-3}$ ). TSPs were also analyzed for 11 heavy metals (Al, Ca, Cu, Mg, Fe, Mn, Zn, Ni, Cr, K, and V) using x-ray fluorescence (XRF) spectrometry. The Fe, Km and $\mathrm{Zn}$ concentrations were higher than other elements and they differed significantly among the studied areas. The present study showed that the concentrations of measured elements decreased in the order of industrial $>$ urban $>$ residential.
\end{abstract}

Keywords: particulate matter, trace metals, XRF, Jeddah

*e-mail: ihassan_eg@yahoo.com 


\section{Introduction}

Particulate matter (PM) is of great concern due to its impact on air quality and global climate change [1]. Ambient levels and composition of PM depend on the emission sources and metrological conditions [2-6]. PM is a complex mixture of particles of different origins with large surface areas, and the significant portion of its mass is made up of inorganic constituents (trace metals and water-soluble ions), which plays an important role in aerosol chemistry [3]. Therefore, PM is an important environmental indicator for air quality and climate change [7-11].

Saudi Arabia is experiencing a rapid increase in urbanization and industrialization with annual urban population growth rates estimated to be $3.9 \%$ in 2010 [8]. Moreover, the number of motor vehicles has increased substantially $[6,9,12]$. Emissions of pollutants of PM into the atmosphere are increasing rapidly with urbanization, industrialization, and increased numbers of motor vehicles, which would reduce visibility, damage natural vegetation, affect public health, increase risks, and worsen life quality [14-15].

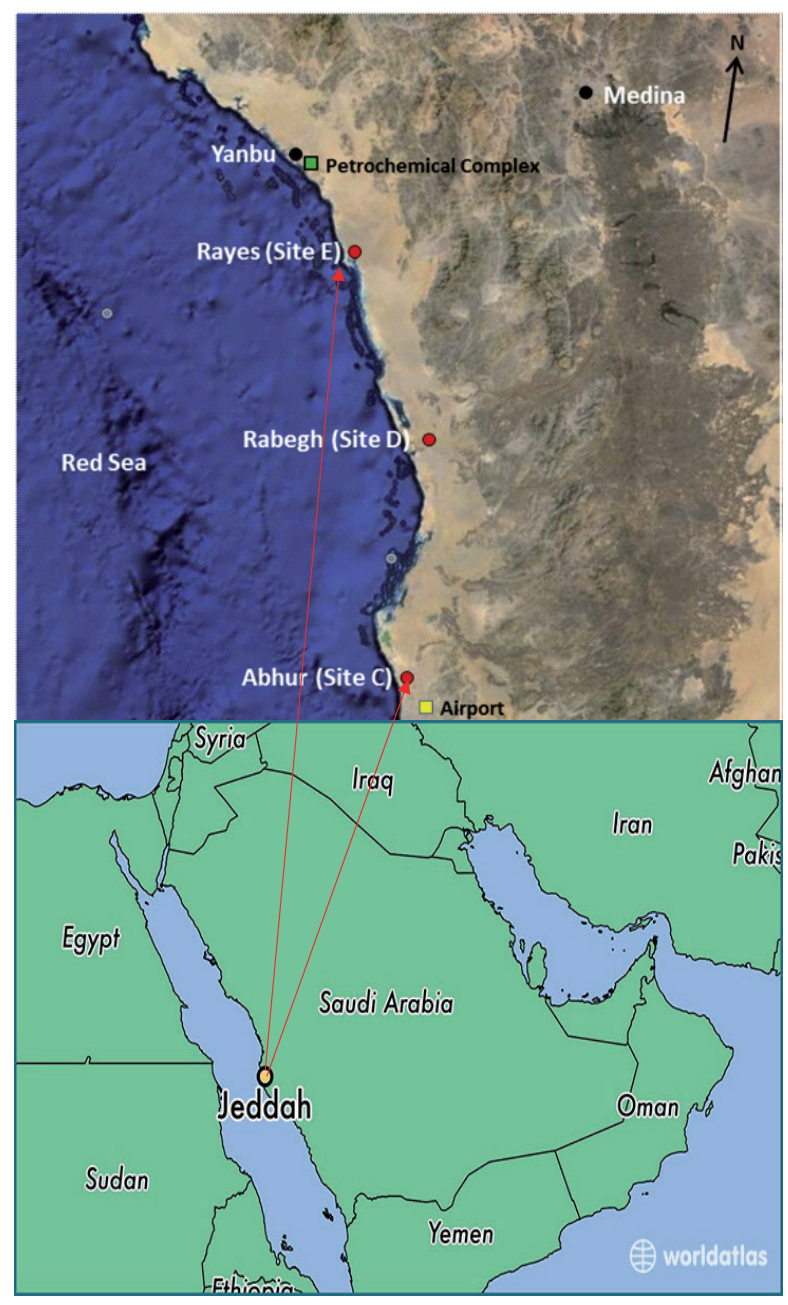

Fig. 1. Map of the western coast of Saudi Arabia showing the sampling locations.
Table 1. Concentrations of TSP at the study sites.

\begin{tabular}{|c|c|c|c|c|}
\hline \multirow{2}{*}{$\begin{array}{c}\text { Experimental } \\
\text { Site }\end{array}$} & $\begin{array}{c}\text { Number of } \\
\text { samples }\end{array}$ & Min & Max & Mean \\
\cline { 2 - 5 } $\begin{array}{c}\text { Rayes } \\
\text { (industrial) }\end{array}$ & 23 & 73 & 883 & 225 \\
\hline $\begin{array}{c}\text { Rabegh } \\
\text { (urban) }\end{array}$ & 24 & 64 & 251 & 121 \\
\hline $\begin{array}{c}\text { Abhur } \\
\text { (residential) }\end{array}$ & 21 & 54 & 339 & 98 \\
\hline \multicolumn{4}{|c|}{ Spatial Variation } & $* * *$ \\
\hline
\end{tabular}

$* * * \mathrm{p}<0.001$

a)

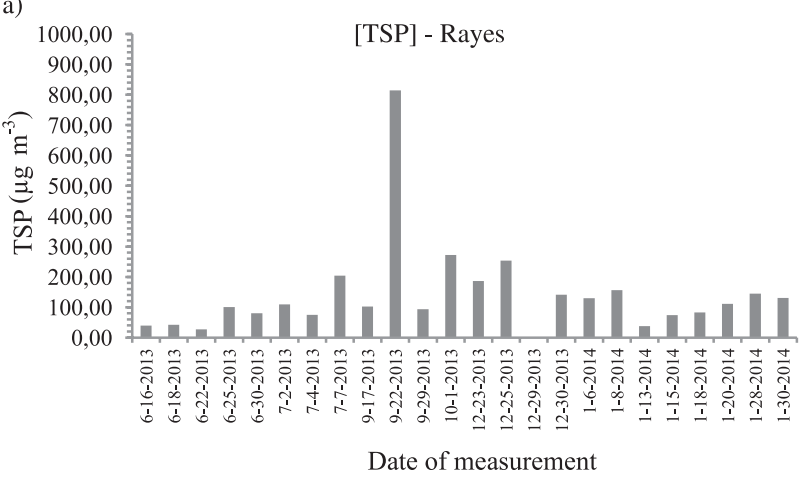

b)
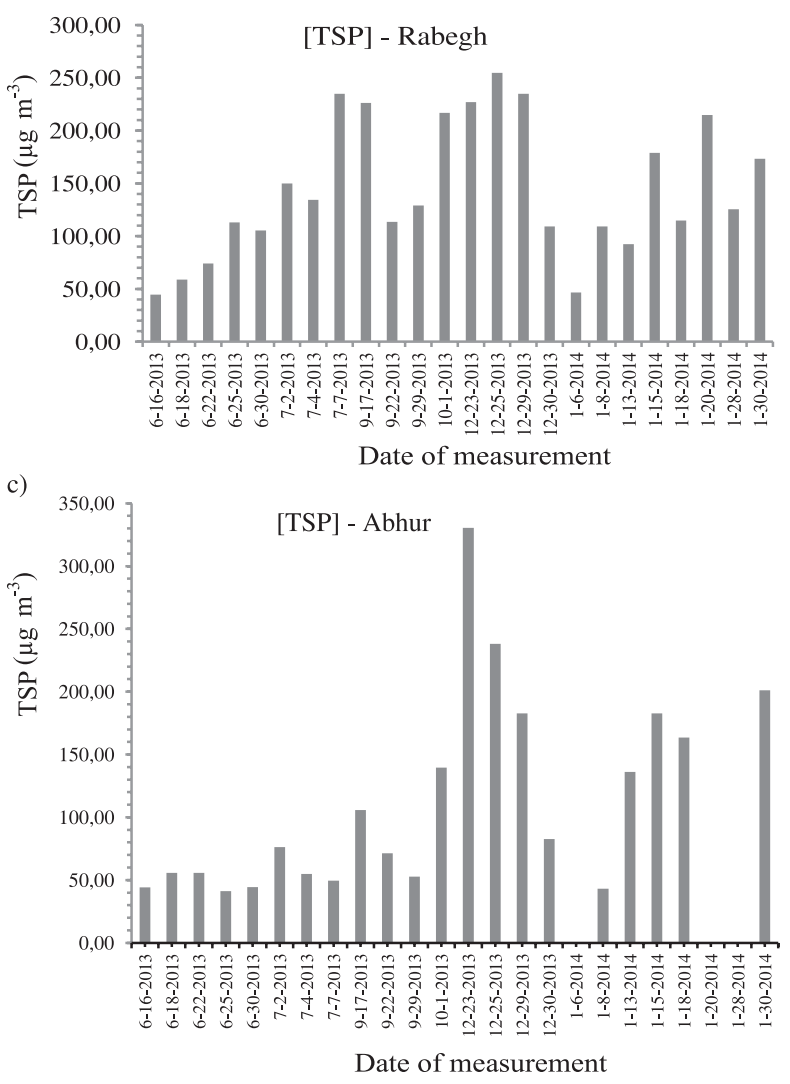

Fig. 2. Average daily concentrations of TSP $\left(\mu \mathrm{g} \mathrm{m}^{-3}\right)$ at a) Rayes, b) Rabegh, and c) Abhur. 
Table 2. Spatial variation of selected trace metals $\left(\mu \mathrm{g} \mathrm{m}^{-3}\right)$; figures are means $\pm \mathrm{SD}$.

\begin{tabular}{|c|c|c|c|c|c|c|c|}
\hline \multirow{3}{*}{ Element } & \multicolumn{7}{|c|}{ Site } \\
\hline & \multicolumn{2}{|c|}{$\begin{array}{c}\text { Rayes } \\
(\mathrm{n}=23)\end{array}$} & \multicolumn{2}{|c|}{$\begin{array}{l}\text { Rabegh } \\
(\mathrm{n}=24)\end{array}$} & \multicolumn{2}{|c|}{$\begin{array}{c}\text { Abhur } \\
(\mathrm{n}=21)\end{array}$} & \multirow[t]{2}{*}{ Spatial Variation } \\
\hline & Mean & S.D. & Mean & S.D. & Mean & S.D. & \\
\hline $\mathrm{Al}$ & 0.018 & 0.033 & 0.002 & 0.021 & 0.041 & 0.031 & $* *$ \\
\hline $\mathrm{Ca}$ & 0.130 & 0.028 & 0.050 & 0.023 & 0.080 & 0.041 & $* * *$ \\
\hline $\mathrm{Cu}$ & 0.131 & 0.023 & 0.062 & 0.008 & 0.003 & 0.002 & $* *$ \\
\hline $\mathrm{Mg}$ & 0.094 & 0.026 & 0.063 & 0.017 & 0.082 & 0.022 & $* *$ \\
\hline $\mathrm{Fe}$ & 0.368 & 0.094 & 0.186 & 0.059 & 0.131 & 0.066 & $* *$ \\
\hline $\mathrm{Mn}$ & 0.086 & 0.008 & 0.040 & 0.005 & 0.003 & 0.002 & $* *$ \\
\hline $\mathrm{Zn}$ & 0.180 & 0.072 & 0.091 & 0.041 & 0.035 & 0.021 & $* * *$ \\
\hline $\mathrm{Ni}$ & 0.084 & 0.064 & 0.081 & 0.033 & 0.086 & 0.058 & -- \\
\hline $\mathrm{Cr}$ & 0.101 & 0.076 & 0.065 & 0.005 & 0.003 & 0.003 & $* * *$ \\
\hline $\mathrm{K}$ & 0.261 & 0.088 & 0.094 & 0.062 & 0.051 & 0.043 & $* *$ \\
\hline V & 0.003 & 0.002 & 0.002 & 0.002 & 0.001 & 0.001 & -- \\
\hline Total & \multicolumn{2}{|c|}{1.456} & \multicolumn{2}{|c|}{0.736} & \multicolumn{2}{|c|}{0.489} & $* * *$ \\
\hline
\end{tabular}

The arid environment and vast deserts of Saudi Arabia have increased the frequency of dust storms along with their intensity and duration [16]. Moreover, there is a lack of awareness regarding air pollution and its impact on ecosystems in Saudi Arabia.

The main goals of the present study were to determine the concentrations of total suspended particles (TSP) and associated trace metals along a gradient of urbanization on the western coast of Saudi Arabia.

\section{Experimental}

\section{Sampling}

Three areas were selected for the present study to present different gradients of urbanization, namely Rayes $\left(23.5756^{\circ} \mathrm{N} 38.6058^{\circ} \mathrm{E}\right)$, Rabegh $\left(22.8122^{\circ} \mathrm{N} 39.0664^{\circ} \mathrm{E}\right)$, and Abhur $\left(21.7572^{\circ} \mathrm{N} 39.1147^{\circ} \mathrm{E}\right)$ (Fig. 1). Samples were collected using a "pesticide" sampler (TE-PUF, Tisch Environmental Inc.) simultaneously at the three

Table 3a. Correlation matrix for TSP and trace metals in Rayes (bold figures are significant at $\mathrm{P}<0.05$ ).

\begin{tabular}{|c|c|c|c|c|c|c|c|c|c|c|c|}
\hline $\mathrm{TSP}$ & $\mathrm{Al}$ & $\mathrm{Ca}$ & $\mathrm{Cu}$ & $\mathrm{Mg}$ & $\mathrm{Fe}$ & $\mathrm{Mn}$ & $\mathrm{Zn}$ & $\mathrm{Ni}$ & $\mathrm{Cr}$ & $\mathrm{K}$ & $\mathrm{V}$ \\
\hline $\mathrm{TSP}$ & $\mathbf{0 . 6 7}$ & $\mathbf{0 . 5 8}$ & $\mathbf{0 . 6 7}$ & 0.83 & 0.97 & 0.55 & 0.64 & 0.67 & 0.52 & 0.59 & 0.77 \\
\hline & $\mathrm{Al}$ & $\mathbf{0 . 7 7}$ & -0.18 & $\mathbf{0 . 6 7}$ & $\mathbf{0 . 7 9}$ & $\mathbf{0 . 8 8}$ & 0.11 & $\mathbf{0 . 5 9}$ & $\mathbf{0 . 6 9}$ & $\mathbf{0 . 9 9}$ & $\mathbf{0 . 9 6}$ \\
\hline & & $\mathrm{Ca}$ & 0.27 & 0.41 & $\mathbf{0 . 6 7}$ & $\mathbf{0 . 5 9}$ & $\mathbf{0 . 7 7}$ & 0.33 & -0.27 & -0.37 & $\mathbf{0 . 6 8}$ \\
\hline & & & $\mathrm{Cu}$ & 0.39 & 0.22 & 0.38 & -0.37 & 0.18 & -0.18 & -0.27 & 0.41 \\
\hline & & & & $\mathrm{Mg}$ & $\mathbf{0 . 9 9}$ & $\mathbf{0 . 5 1}$ & 0.49 & 0.50 & -0.23 & -0.19 & -0.28 \\
\hline & & & & & $\mathrm{Fe}$ & 0.99 & -0.28 & -0.44 & -0.42 & 0.37 & 0.29 \\
\hline & & & & & & $\mathrm{Mn}$ & 0.65 & 0.44 & -0.28 & -0.41 & -0.37 \\
\hline & & & & & & & $\mathrm{Zn}$ & 0.51 & 0.21 & -0.11 & 0.25 \\
\hline & & & & & & & & $\mathrm{Ni}$ & $\mathbf{0 . 6 1}$ & $\mathbf{0 . 5 3}$ & 0.38 \\
\hline & & & & & & & & & $\mathrm{Cr}$ & $\mathbf{0 . 7 4}$ & 0.41 \\
\hline
\end{tabular}


Table 3b. Correlation matrix for TSP and trace metals in Rabegh (bold figures are significant at $\mathrm{P}<0.05$ ).

\begin{tabular}{|c|c|c|c|c|c|c|c|c|c|c|c|}
\hline $\mathrm{TSP}$ & $\mathrm{Al}$ & $\mathrm{Ca}$ & $\mathrm{Cu}$ & $\mathrm{Mg}$ & $\mathrm{Fe}$ & $\mathrm{Mn}$ & $\mathrm{Zn}$ & $\mathrm{Ni}$ & $\mathrm{Cr}$ & $\mathrm{K}$ & $\mathrm{V}$ \\
\hline $\mathrm{TSP}$ & $\mathbf{0 . 5 6}$ & $\mathbf{0 . 8 7}$ & 0.58 & 0.61 & 0.66 & 0.98 & 0.88 & 0.67 & 0.59 & 0.67 & 0.53 \\
\hline & $\mathrm{Al}$ & $\mathbf{0 . 9 9}$ & $\mathbf{0 . 6 8}$ & $\mathbf{0 . 5 5}$ & $\mathbf{0 . 5 4}$ & $\mathbf{0 . 6 5}$ & $\mathbf{0 . 5 7}$ & $\mathbf{0 . 8 8}$ & 0.44 & $\mathbf{0 . 7 5}$ & 0.55 \\
\hline & & $\mathrm{Ca}$ & $\mathbf{0 . 8 7}$ & $\mathbf{0 5 4}$ & $\mathbf{0 . 7 7}$ & $\mathbf{0 . 7 8}$ & 0.42 & $\mathbf{0 . 6 9}$ & 0.49 & $\mathbf{0 . 6 5}$ & 0.50 \\
\hline & & & $\mathrm{Cu}$ & $\mathbf{0 5 9}$ & $\mathbf{0 . 9 8}$ & $\mathbf{0 . 9 9}$ & 0.33 & 0.47 & 0.56 & $\mathbf{0 . 5 9}$ & 0.44 \\
\hline & & & & $\mathrm{Mg}$ & $\mathbf{0 . 9 9}$ & $\mathbf{0 . 8 6}$ & 0.49 & 0.42 & 0.33 & $\mathbf{0 . 8 7}$ & 0.36 \\
\hline & & & & & $\mathrm{Fe}$ & $\mathbf{0 . 6 7}$ & $\mathbf{0 . 7 8}$ & $\mathbf{0 . 8 3}$ & $\mathbf{0 . 8 5}$ & $\mathbf{0 . 6 9}$ & $\mathbf{0 . 8 9}$ \\
\hline & & & & & & $\mathrm{Mn}$ & $\mathbf{0 . 8 7}$ & $\mathbf{0 . 9 8}$ & $\mathbf{0 . 8 8}$ & $\mathbf{0 . 7 8}$ & $\mathbf{0 . 6 3}$ \\
\hline & & & & & & & $\mathrm{Zn}$ & $\mathbf{0 . 6 7}$ & $\mathbf{0 . 7 4}$ & 0.46 & 0.52 \\
\hline & & & & & & & & $\mathrm{Ni}$ & $\mathbf{0 . 7 6}$ & $\mathbf{0 . 6 2}$ & $\mathbf{0 . 6 7}$ \\
\hline & & & & & & & & & $\mathrm{Cr}$ & $\mathbf{0 . 6 3}$ & 0.58 \\
\hline & & & & & & & & & & $\mathrm{K}$ & $\mathbf{0 . 7 9}$ \\
\hline & & & & & & & & & & $\mathrm{V}$ \\
\hline
\end{tabular}

Table 3c. Correlation matrix for TSP and trace metals in Abhur (bold figures are significant at $\mathrm{P}<0.05$ ).

\begin{tabular}{|c|c|c|c|c|c|c|c|c|c|c|c|}
\hline $\mathrm{TSP}$ & $\mathrm{Al}$ & $\mathrm{Ca}$ & $\mathrm{Cu}$ & $\mathrm{Mg}$ & $\mathrm{Fe}$ & $\mathrm{Mn}$ & $\mathrm{Zn}$ & $\mathrm{Ni}$ & $\mathrm{Cr}$ & $\mathrm{K}$ & $\mathrm{V}$ \\
\hline $\mathrm{TSP}$ & $\mathbf{0 . 5 5}$ & 0.56 & 0.66 & 0.71 & 0.53 & 0.59 & 0.57 & 0.69 & 0.61 & 0.58 & 0.66 \\
\hline & $\mathrm{Al}$ & 0.50 & $\mathbf{0 . 5 4}$ & $\mathbf{0 . 5 8}$ & $\mathbf{0 . 6 9}$ & $\mathbf{0 . 6 5}$ & $\mathbf{0 . 5 5}$ & $\mathbf{0 . 5 5}$ & $\mathbf{0 . 5 1}$ & 0.67 & 0.54 \\
\hline & & $\mathrm{Ca}$ & -0.42 & $\mathbf{0 . 5 8}$ & $\mathbf{0 . 7 6}$ & $\mathbf{0 . 8 6}$ & 0.48 & 0.43 & 0.38 & 0.28 & 0.32 \\
\hline & & & $\mathrm{Cu}$ & 0.49 & 0.48 & $\mathbf{0 . 5 7}$ & $\mathbf{0 . 8 7}$ & 0.39 & $\mathbf{0 . 7 8}$ & $\mathbf{0 . 8 9}$ & -0.34 \\
\hline & & & & $\mathrm{Mg}$ & -0.43 & $\mathbf{0 . 5 2}$ & 0.44 & 0.50 & $\mathbf{0 . 5 4}$ & 0.48 & 0.38 \\
\hline & & & & & $\mathrm{Fe}$ & $\mathbf{0 . 7 9}$ & 0.51 & $\mathbf{0 . 6 6}$ & $\mathbf{0 . 6 6}$ & $\mathbf{0 . 6 7}$ & $\mathbf{0 . 6 7}$ \\
\hline & & & & & & $\mathrm{Mn}$ & $\mathbf{0 . 7 8}$ & $\mathbf{0 . 8 3}$ & -0.37 & 0.76 & 0.49 \\
\hline & & & & & & & $\mathrm{Zn}$ & -0.32 & 0.33 & 0.93 & 0.36 \\
\hline & & & & & & & & $\mathrm{Ni}$ & -0.26 & 0.37 & $\mathbf{0 . 5 5}$ \\
\hline & & & & & & & & & $\mathrm{Cr}$ & 0.26 & -0.09 \\
\hline & & & & & & & & & & $\mathrm{K}$ & -0.15 \\
\hline & & & & & & & & & & & $\mathrm{V}$ \\
\hline
\end{tabular}

sites between 16 June to 7 July 2013, 17 September to 1 October 2013 (summer), and 23 December 2013 to 30 January 2014 (winter) [10]. Peak hourly temperatures ranged from $38-47^{\circ} \mathrm{C}$ and $23-30^{\circ} \mathrm{C}$ (summer and winter).

Filters were preheated at $500^{\circ} \mathrm{C}$ for $24 \mathrm{~h}$, wrapped in a clean foil, and placed in airtight glass containers. The sampling was conducted for 24 hours at all sites and the mass of TSPs was determined by weighing the filter before and after sampling using a microbalance (model MT5, Mettler-Toledo Inc.) in a temperature- and humidity-controlled weighing room. The mass on the quartz microfibre filter was measured.

\section{Element Metal Analysis}

The concentration of metals was analyzed using a non-destructive X-ray fluorescence (XRF) spectrometer (S2 PICOFOX, BURKER). Qualitative multi-element spectral measurement and analysis were carried out simultaneously [16].

\section{Data Analysis}

Data were subjected to a one-way analysis of variance (ANOVA) and means were separated using Tukey's 
multiple comparison test ( $p>0.05)$ to assess the significant difference among the mean values of different attributes from different sites.

The relationships between concentrations of TSP and different elements at different sites were analyzed using the correlation coefficient test. All analyses were performed using SPSS 16.0 statistical package (SPSS Inc., USA)

\section{Results and Discussion}

The Temporal distribution of TSP at the three sites is illustrated in Fig. 2, while the minimum, maximum, and average arithmetic mean values for TSP are presented in Table 1. The mean concentrations were 225, 121, and $98 \mu \mathrm{g} \mathrm{m}^{-3}$ at Rayes, Rabegh, and Abhur, respectively (i.e., TSPs were in the order of Rayes $>$ Rabegh $>$ Abhur). However, there are extreme values for Rayes $\left(883 \mu \mathrm{g} \mathrm{m}^{-3}\right.$ on 23 Sept.), Rabegh $\left(251,240\right.$, and $229 \mu \mathrm{g} \mathrm{m}^{-3}$ on 26 Dec., 8 July, and 30 Dec. , respectively; Fig. 2 b) and for Abhur the extreme record was $339 \mu \mathrm{g} \mathrm{m}^{-3}$ on $24 \mathrm{Dec}$. If these extreme values are not included in the average TSP, then the averages in these sites would be $210.11,135.37$, and $67.64 \mu \mathrm{gm}^{-3}$, respectively, (Table 1, Figs 1a-c).

These extreme values occurred on days when dust storms passed through the western coast of Saudi Arabia. Dust storms in Saudi Arabia occur around six to seven times per year, especially in the spring and fall. At that time of year, air quality deteriorates and visibility is greatly reduced $[8-9,17]$. However, the samplings were carried out during summer and winter in the present study and there were two dust storms during those times.

The General Authority of Meteorology and Environment in Saudi Arabia has established air quality standards (AQA), and it states that the guidelines for TSP for a 12-month period outdoors should not exceed $80 \mu \mathrm{g} \mathrm{m} \mathrm{m}^{-3}$. This PME guideline has been exceeded 10 times at Abhur and 20 times at the other locations (Figs 2a-c). However, these concentrations are much lower than those recorded in Riyadh (578-662 $\left.\mu \mathrm{g} \mathrm{m}^{-3}\right)$ and in Makkah (336.4 $\left.\mu \mathrm{g} \mathrm{m}^{-3}\right)$ in Saudi Arabia [15].

Similarly, the sum of the concentrations of measured elements were in the order of Rayes $>$ Rabegh $>$ Abhur. The total concentration of measured elements were $1.456,0.736$, and $0.489 \mu \mathrm{g} \mathrm{m}^{-3}$ at these sites respectively (Table 2).

The highest concentrations recorded were 0.368 , $0.261,0.180,0.131$, and $0.130 \mu \mathrm{g} \mathrm{m}^{-3}$ for $\mathrm{Fe}, \mathrm{K}, \mathrm{Zn}, \mathrm{Cu}$, and $\mathrm{Ca}$, respectively, at the industrial site (Rayes), while at the urban site (Rabegh) the highest concentrations recorded were $0.186,0.094$, and $0.091 \mu \mathrm{g} \mathrm{m}^{-3}$ for $\mathrm{Fe}, \mathrm{K}$, and $\mathrm{Zn}$, respectively (Table 2). At the residential (Abhur), which is the southern site, $\mathrm{Fe}, \mathrm{Ni}, \mathrm{Mg}$, and $\mathrm{Ca}$ had the highest concentrations $(0.131,0.086,0.082$, and $0.08 \mu \mathrm{g} \mathrm{m} \mathrm{m}^{-3}$, respectively; Table 2). Elements varied significantly $(0.05<\mathrm{P}<0.01)$ among sites (Table 2$)$.

Duan et al. [17] attributed the high concentrations of $\mathrm{Ca}$ at their field sites to construction activities; this could be the case at the Rayes site in our study.
The correlation matrix for various metals and TSP is shown in Table 3. TSPs were correlated significantly to all elements $(\mathrm{r}>0.5)$. Fe, $\mathrm{Mn}$, and $\mathrm{Mg}$ had the highest correlations $\left(\mathrm{r}=0.97,0.98\right.$, and $0.71 \mu \mathrm{g} \mathrm{m}^{-3}$ at Rayes, Rabegh, and Abhur, respectively) with TSP (Table 3ac). As for the metal-to-metal correlation, Al is highly correlated with $\mathrm{K}(\mathrm{r}=0.99)$ and $\mathrm{Mg}$ is highly correlated with Fe $(r=0.99)$ at the Rayes site (Table 3a). Moreover, $\mathrm{V}$ was highly correlated with $\mathrm{Al}(\mathrm{r}=0.96)$ at the same site.

At Rabegh, $\mathrm{Cu}$ was highly correlated with $\mathrm{Mn}$ and $\mathrm{Fe}$ ( $r=0.99,0.98$, respectively), and $\mathrm{Mg}$ was significantly correlated with Fe $(r=0.99)$. Similarly, Mn was highly correlated with $\mathrm{Ni}(\mathrm{r}=0.98)$ (Table $3 \mathrm{~b})$.

On the southern site, Abhur, the correlation was lower than that in the northern sites (Rayes and Rabegh), but still highly significant. The highest correlations recorded were between $\mathrm{Cu}$ and $\mathrm{K}(\mathrm{r}=0.89), \mathrm{Ca}$ and $\mathrm{Mg}(\mathrm{r}=0.89)$, and $\mathrm{Mn}$ and $\mathrm{Ni}(\mathrm{r}=0.83)$ (Table 3c). The correlation between $\mathrm{V}$ and $\mathrm{Ni}$ was high $(\mathrm{r}=0.55$ and 0.67 at Rabegh and Abhur, respectively), and it is often used as tracers for oil combustion [17].

\section{Conclusions}

Ambient concentrations of TSP and their elemental composition at the three different sites - Rayes (industrial), Rabegh, (urban), and Abhur (residential) along the western coast of Saudi Arabia - are presented in this investigation for elucidating the chemical characteristics of aerosols. The concentrations of TSP exceeded the daily

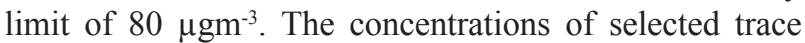
metals in aerosol at Rayes were the highest among the three sites. Industrial processes, vehicle emissions, and road dust are the main source-types affecting the local atmosphere. The results of the present study may help researchers and policymakers to manage and develop strategies for air pollution control and abatement in order to improve air quality to protect people from the hazardous effects arising from elevated atmospheric trace metals.

It is necessary to carry out specific size-segregated PM studies in the region in order to provide more information on the maximum size of particles being sampled.

\section{Acknowledgements}

This work was funded by a grant from the Deanship of Scientific Research at KAU (project No. 1/H/1435). The authors are indebted to anonymous reviewers for their valuable comments, and we are thankful for the technical support of Mr. A. Al Eryani, A. Al Ghamdi, and A. Al Zahrani.

\section{References}

1. ALGHAMDI M. A., SHAMY M., REDAL M. A., KHODER M., AWAD A. A., ELSEROUGYE S. Microorganisms 
associated particulate matter: A preliminary study. Sci Total Environ 479-480, 109, 2014.

2. YIN J., HARRISON R.M. Pragmatic mass closure study for $\mathrm{PM}_{1.0}, \mathrm{PM}_{2.5}$ and $\mathrm{PM}_{10}$ at roadside, urban background and rural sites. Atmospheric Environ 42, 980, 2008.

3. HASSAN I.A., BASAHI J. Assessing roadside conditions and vehicular missions using roadside lettuce plants. Polish J. Environ. Stud. 22, 75, 2013.

4. TAIWO A.M., DAVID C.S., SHI B.Z., HARRISON R.M. Mass and number size distributions of particulate matter components: Comparison of an industrial site and an urban background site. Sci. Total Environ 475, 29, 2014.

5. SIPPULA O., RINTALA H., HAPPO M., JALAVA P., KUUSPALO K., VIRÉN A. Characterization of chemical and microbial species from size-segregated indoor and outdoor particulate samples. Aerosol Air Quality Research 13, 1212, 2013.

6. QARI H.A., HASSAN I.A. Bioaccumulation of PAHs in Padina boryana alga collected from a contaminated site at the Red sea, Saudi Arabia. Polish J. Environ. Stud. 27 (1), 2017.

7. EL-ASKARY H., FAROUK H.R., ICHOKU C., KAFATOS M. Transport of dust and anthropogenic aerosols across Alexandria, Egypt. Annual J. Geophys. 27, 2869, 2009.

8. ALGHAMDI M.A., ALAM M.S., YIN J., STARK C., JANG E., HARRISON R.M., SHAMY M., KHODER M.I., SHABBAJ I.I. Receptor modeling study of polycyclic aromatic hydrocarbons in Jeddah, Saudi Arabia. Sci Total Environ 506-507, 401, 2015.

9. ALGHAMDI M.A, ALMAZROUI M., SHAMY M., REDAL M.A., KHALAF A., KHODER M.I. Characterization and elemental composition of atmospheric aerosol loads during springtime dust storm in western Saudi Arabia. Aerosol Air Qual. Res. 15, 440, 2015.

10. HARRISON R., ALAM S., DANG J., BASAHI J., ALGHAMDI M., ISAMIL I., KHODER M., HASSAN I. Influ- ence of petrochemical installations upon PAH concentrations at sites in Western Saudi Arabia. Atm. Pollut. Res. 7, 954, 2016.

11. AWAN M.A., AHMED S.H. Determination of total suspended particulate matter and heavy metals in ambient air of four cities of Pakistan. Iran. J. Energy Environ 2, 128, 2011.

12. HARRISON R., ALAM S., DANG J., BASAHI J., ALGHAMDI M., ISAMIL I., HASSAN I., KHODER M. Relationship of polycyclic aromatic hydrocarbons with oxy (quinone) and nitro derivatives during air mass transport. Sci Total Environ 572, 1175, 2016.

13. VICENTE A.B., SANFELIU T., JORDAN M.M. Comparison between industrial-urban and rural particle stations in a ceramic cluster (NE, Spain). Water Air Soil Pollut. 215, 83, 2011.

14. HABEEBULLAH T.M. Chemical Composition of Particulate Matters in Makkah - Focusing on Cations, Anions and Heavy Metals. Aerosol Air Quality Research 16, 336, 2016.

15. MUNIR S., HABEEBULLAH T.M., SEROJI A.R., MORSY E.A., MOHAMMED A.M.F., ABU SAUD W., ABDOU A.E., AWAD A.A. Modeling Particulate Matter Concentrations in Makkah, Applying a Statistical Modeling Approach. Aerosol Air Qual. Res. 13, 901, 2103.

16. OKUDA T., FUJIMORI E., HATOYA K., TAKADA H., KUMATA H., NAKAJIMA F., HARAGUCHI H. Rapid and simple determination of multi-elements in aerosol samples collected on quartz fiber filters by using EDXRF coupled with fundamental parameter quantification technique. Aerosol Air Qual. Res. 13, 1864, 2013.

17. DUAN K., TAN J., WANG S., HAO J., CHAI F. Size distribution and sources of elements in particulate matter at curbside, urban and rural sites in Beijing. J. Environ. Sci. 24, 87, 2012. 